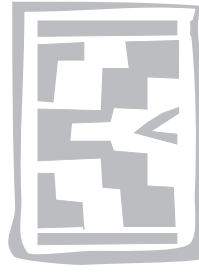

\title{
2-Phenoxyethanol as anaesthetic in removing and relocating 102 species of fishes representing 30 families from Sea World to uShaka Marine World, South Africa
}

\author{
D.B. VAUGHAN1* ${ }^{*}$ M.R. PENNING ${ }^{2}$ and K.W. CHRISTISON ${ }^{3}$
}

\begin{abstract}
VAUGHAN, D.B., PENNING, M.R. \& CHRISTISON, K.W. 2008. 2-Phenoxyethanol as anaesthetic in removing and relocating 102 species of fishes representing 30 families from Sea World to uShaka Marine World, South Africa. Onderstepoort Journal of Veterinary Research, 75:189-198

2-Phenoxyethanol was used as an anaesthetic to translocate 102 species of fishes representing 30 families from the Sea World aquarium on Durban's beachfront to uShaka Marine World. Most fishes responded well to a final anaesthetic concentration of $0,150 \mathrm{~m} / / \ell$ and there were no mortalities.
\end{abstract}

Keywords: Anaesthetic, fishes, 2-Phenoxyethanol, public aquarium, translocation

\section{INTRODUCTION}

The South African Association for Marine Biological Research, incorporating Sea World, Oceanographic Research Institute and the Dolphinarium relocated from their old premises of 46 years on Durban's beach front in March and April 2004 to the new Point Development's marine theme park, uShaka Marine World in Durban, South Africa. Netting of fishes from the large exhibits could cause physical damage to struggling fishes, increasing the risk of opportunistic secondary bacterial infections (Inoue, dos Santos Neto \& Morales 2004) which could not be treated in time for the opening of uShaka Marine World on 30 April 2004. An ideal method to facilitate the removal

* Author to whom correspondence is to be directed. Email: dvaughan@aquarium.co.za

1 Two Oceans Aquarium, Dock Road, Victoria and Alfred Waterfront, Cape Town, 8000 South Africa

2 South African Association for Marine Biological Research, uShaka Marine World, 1 King Shaka Avenue, Point precinct, Durban, 4000 South Africa

3 Department of Biodiversity and Conservation Biology, University of the Western Cape, Private Bag X17, Bellville, 7535 South Africa

Accepted for publication 21 April 2008-Editor of fishes from exhibits would be the use of a general anaesthetic. Characteristics of a suitable anaesthetic for this purpose would include ease of administration and stability, rapid recovery of anaesthetised fishes once re-introduced into untreated water and the dependency of anaesthetic duration upon concentration (Dunn \& Koester 1985). "2-Phenoxyethanol" (MercK Laboratories, Johannesburg) was selected to facilitate the removal of fishes from the two main aquarium exhibits, the open ocean exhibit, housing the highest diversity of fishes (Table 1), and the shark tank housing two large adult Zambezi sharks, Carcharhinus leucas Valenciennes, 1839, eight adult Spotted ragged-tooth sharks, Carcharias taurus Rafinesque, 1810, and several sympatric teleost species (Table 2). 2-Phenoxyethanol is relatively inexpensive and remains viable in long-term exposure (Kaiser \& Vine 1998) and is also available in bulk in South Africa. Deacon, White \& Hecht (1997) recommend 2-Phenoxyethanol as a highly suitable anaesthetic for repeatedly exposed fishes. 2-Phenoxyethanol also showed a more notable sedation than MS-222 in an experiment on Gilthead sea bream, Sparus aurata (Molinero \& Gonzalez 1995) and is considered a desirable anaesthetic for the transportation of fishes by Yanar \& Kumlu (2001). 
Pole syringe anaesthetic technique using ketamine hydrochloride and xylazine hydrochloride was not feasible for facilitating translocation of the $C$. leucas, and $C$. taurus, weighing in excess of $170 \mathrm{~kg}$ each because of the restriction in dart-syringe size and therefore efficient dosage administration. Repeated darting could not guarantee successful induction or the safety of the operator. Each exhibit of fishes was moved separately on different days.

\section{MATERIAL AND METHODS}

The shark tank was first to have its animals relocated on 13 April 2004. The fishes in the open ocean exhibit were relocated 2 days later. Incoming seawater supplies and filtration systems were shut down. Aeration of both exhibits was maintained for circulation and sustaining desirable dissolved oxygen levels during the procedure. The shark tank and the open ocean exhibit volumes were calculated at $386400 \ell$ and $850500 \ell$, respectively. Temperature, dissolved oxygen and $\mathrm{pH}$ levels were monitored using a YSI 85 hand-held temperature, dissolved oxygen, conductivity and salinity meter, and a Cyberscan $\mathrm{pH}$ and ORP meter.

2-Phenoxyethanol was thoroughly mixed with tap water in $450 \ell$ plastic drums alongside the exhibits and poured directly into the water. Concentration increments of $0.050 \mathrm{~m} \ell / \ell$, equating to $19.32 \ell$ of 2-Phenoxyethanol, were added every $30 \mathrm{~min}$ to the shark tank to a final concentration of $0.150 \mathrm{ml} / \mathrm{l}$. The initial concentration for the open ocean exhibit was $0.030 \mathrm{~m} / \mathrm{l}$ equating to $25 \ell$ of 2 -Phenoxyethanol. After $30 \mathrm{~min}$, increments of $0.006 \mathrm{~m} / \mathrm{l}(5 \ell$ of 2-Phenoxyethanol) were added every 15 min until the concentration of $0.150 \mathrm{~m} \ell / \mathrm{l}$ was obtained. The concentration was increased to $0.250 \mathrm{ml} / \mathrm{l}$ only to anaesthetise the last fish species, Cobia, Rachycentron canadum Linnaeus, 1776, once all other fishes had been removed. Small concentration increments spread over a longer period of time in the open ocean exhibit enabled specific species of fishes of a higher diversity than the shark tank to be removed upon their potential differences in reaction to concentrations and exposure times to 2-Phenoxyethanol.

Excitation events were recorded and the fishes were removed according to their effective induction to anaesthesia upon loss of equilibrium. The Zambezi sharks were guided into PVC stretchers upon the first signs of anaesthesia, after which the Spotted ragged-tooth sharks were similarly removed, to prevent physical injury to themselves through collision with tank walls and viewing panels. All other anaesthetised fishes were collected in transparent PVC bags by a team of divers. They were removed to awaiting transport tanks containing $2000 \ell, 4000 \ell$ or $8000 \ell$ volumes of seawater on the back of two flatbed trucks to be delivered in relay to the new aquarium exhibits. All the transport tanks except one of $2000 \ell$ capacity, contained a 2-Phenoxyethanol concentration of $0.100 \mathrm{ml} / \mathrm{l}$. The untreated transport tank was reserved for potentially sensitive species to the affects of the 2-Phenoxethanol, so that they could be revived quickly to prevent possible mortalities. All transport tanks were separately filtered using diatom cartridge filters on pump-recirculation, and oxygenated using medical-grade oxygen diffused directly into the water via airstones and flexible gas tubing. After transporting and delivery of two loads of fishes to the new aquarium, all the seawater in the transport tanks was drained and replaced and re-dosed with 2-Phenoxyethanol at the same concentration.

\section{RESULTS/OBSERVATIONS}

Water quality parameters throughout the exercise for both exhibits were similar and relatively stable. Temperatures for both exhibits remained unchanged at $22.6^{\circ} \mathrm{C}$, and $22.9^{\circ} \mathrm{C}$ for the open ocean exhibit and shark tank, respectively, with a stable $\mathrm{pH}$ for each exhibit at 7.77 and 7.86 throughout the exercise. Dissolved oxygen levels were measured at the anaesthetic induction time per species. One hundred and two species of fishes representing 30 families were successfully anaesthetised using 2-Phenoxyethanol (Tables 1 and 2). Both Zambezi sharks displayed excitation at $0.100 \mathrm{ml} / \mathrm{l}$ at $50 \mathrm{~min}$, characterised by a marked increase in swimming speed, and became disorientated at $0.150 \mathrm{~m} / \mathrm{l}$ at $72.9 \%$ dissolved oxygen and $70 \mathrm{~min}$, when they were removed promptly to avoid injury. None of the Spotted Ragged-tooth sharks showed any changes in behaviour throughout the procedure and were removed from the shark tank after both $C$. leucas were removed. The remaining fishes were removed by the team of divers from the shark tank after all the sharks had been removed.

All species of the family Carangidae (Kingfishes) from the shark tank displayed excitation (Table 2), yet this was completely absent in all the carangid species in the open ocean exhibit anaesthetised at the same final concentration of $0.150 \mathrm{~m} / / \mathrm{l}$ (Table 1). The Crocodile needlefish, Tylosurus crocodilus crocodilus Peron \& LeSueur, 1821, from the open ocean 


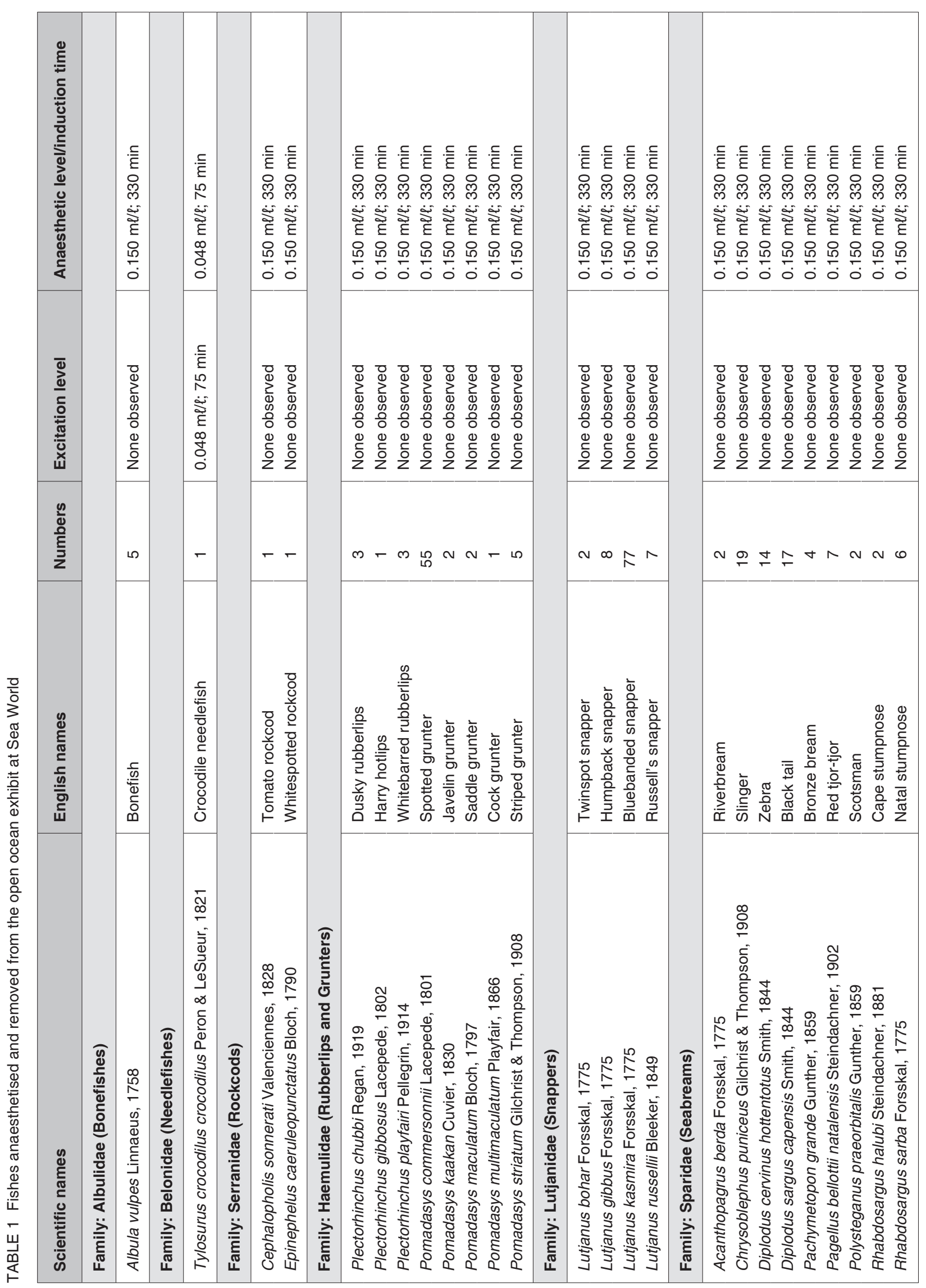




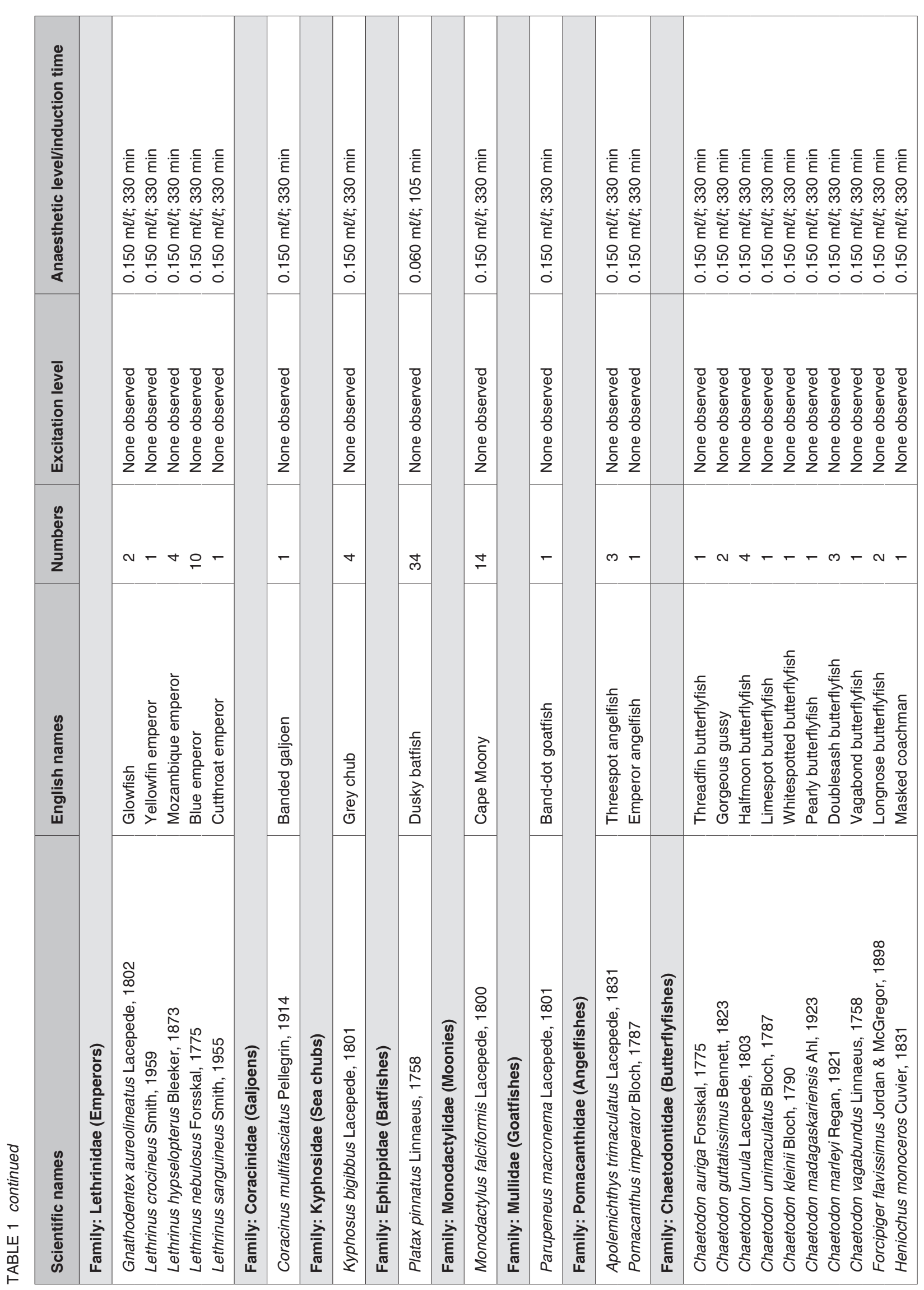




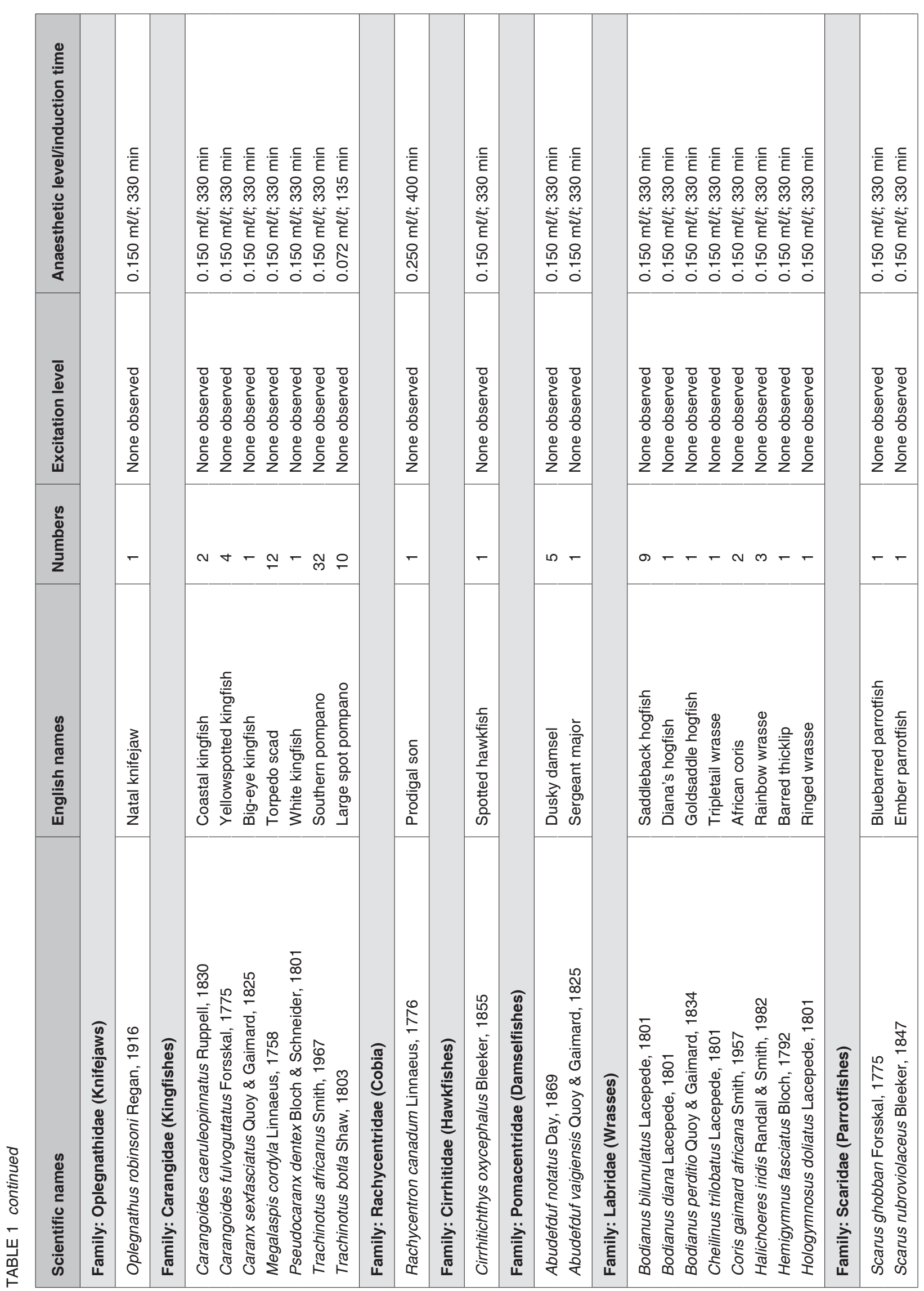




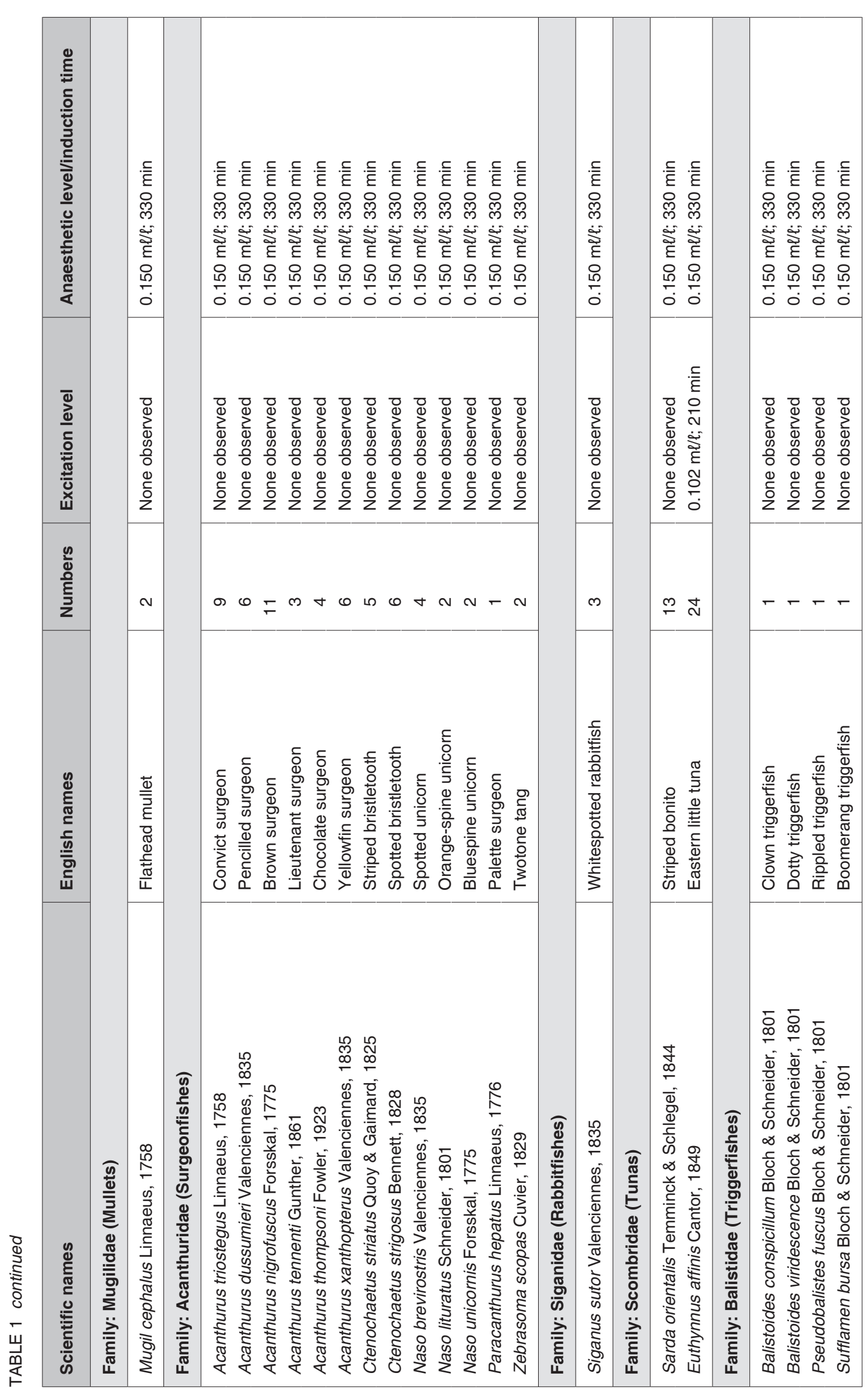




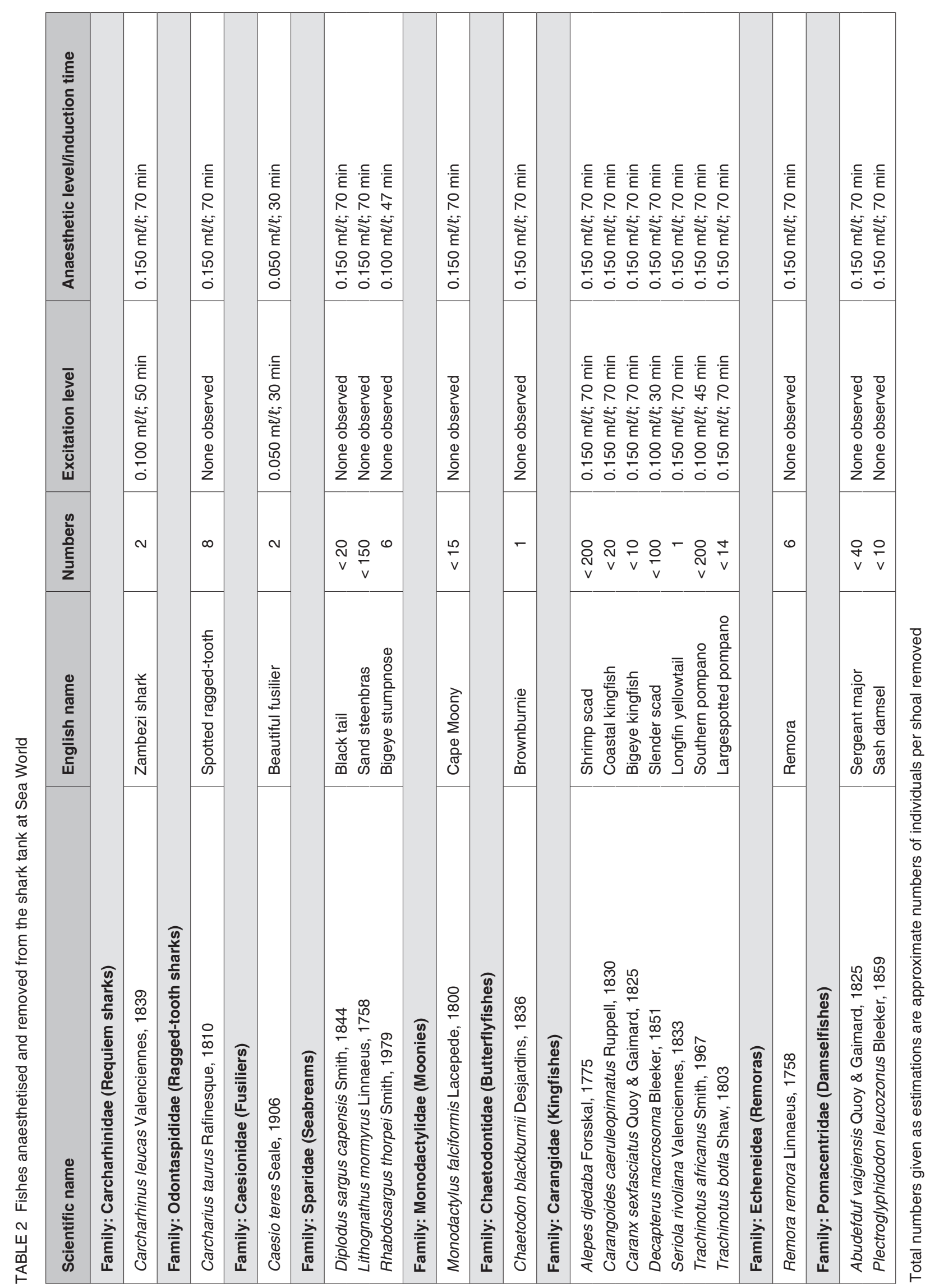




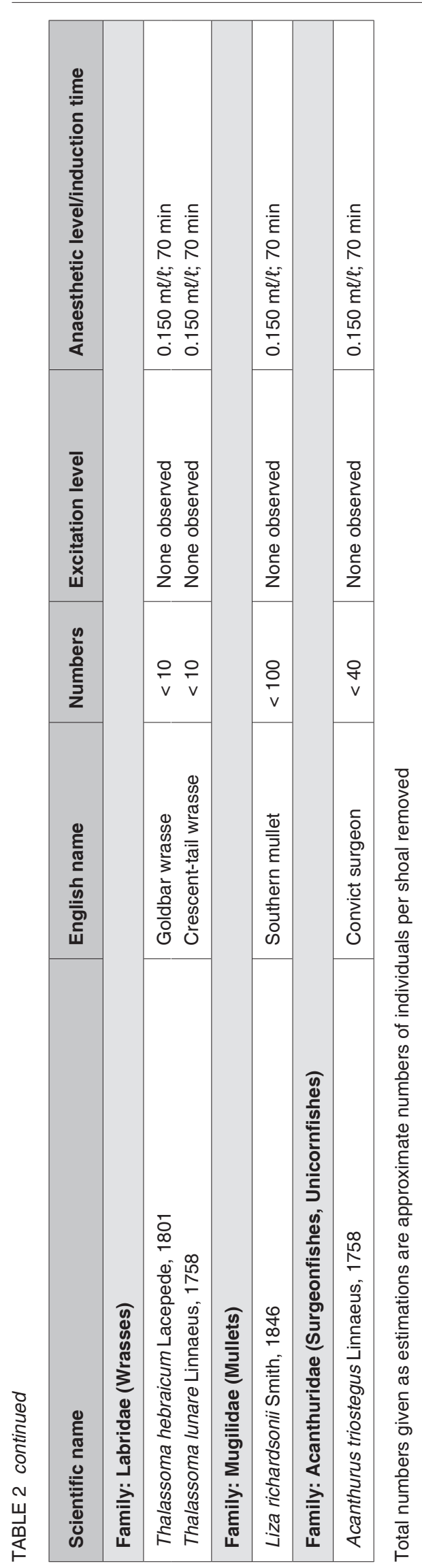


exhibit was the most sensitive of all fishes to 2-Phenoxyethanol. Excitation was brief yet violent, followed by a sudden and complete loss of equilibrium at $0.048 \mathrm{ml} / \mathrm{l}$ and $83.2 \%$ dissolved oxygen after $75 \mathrm{~min}$ after the introduction of the initial increment, and was removed to the untreated transport tank where it made a full recovery. Beautiful fusilier, Caesio teres Seale, 1906 displayed a short period of excitation at $0.050 \mathrm{ml} / \mathrm{l}$ before losing equilibrium at $81.6 \%$ dissolved oxygen and 30 min. Dusky batfish, Platax pinnatus Linnaeus, 1758 became anaesthetised at $0.060 \mathrm{~m} \ell / \ell$ and $78 \%$ dissolved oxygen and $105 \mathrm{~min}$ without excitation. Largespotted pompano, Trachinotus botla Shaw, 1803, from the open ocean exhibit became anaesthetised at $0.072 \mathrm{ml} / \mathrm{l}$ and $71.9 \%$ dissolved oxygen and $135 \mathrm{~min}$, and at $0.150 \mathrm{~m} / \mathrm{l}$ in the shark tank at $72.9 \%$ dissolved oxygen and 70 min. Bigeye stumpnose, Rhabdosargus thorpei Smith, 1979 , became anaesthetised at $0.100 \mathrm{ml} / \mathrm{l}$ at $79.8 \%$ dissolved oxygen and 47 min without displaying excitation. Excitation was evident in the Little Eastern tuna, Euthynnus affinis Cantor, 1849, at $0.102 \mathrm{ml} / \mathrm{l}$ and $210 \mathrm{~min}$, but they only became anaesthetised at $0.150 \mathrm{ml} / \mathrm{l}$ at $71.9 \%$ dissolved oxygen and 330 min. All other fishes except the Cobia, R. canadum, became anaesthetised at $0.150 \mathrm{ml} / \mathrm{l}$ and $71.9 \%$ dissolved oxygen and 330 min without excitation, and were easily removed from the exhibits. The Cobia was the last fish to be removed from the open ocean exhibit after increasing the dosage to $0.250 \mathrm{~m} / \mathrm{\ell}$, at $89.6 \%$ dissolved oxygen and $430 \mathrm{~min}$.

No mortalities resulted from the use of 2-Phenoxyethanol on any of the fishes during anaesthesia or transport to uShaka Marine World.

\section{DISCUSSION}

Hseu, Yeh, Chu \& Ting (1998) outlined a drawback in the use of 2-Phenoxyethanol, in that it requires high anaesthetic concentrations in comparison to MS-222 (Argent Chemical Laboratories) and Quinaldine (SIGMA-ALDRICH) in fishes, and that the effective concentration for most fishes is $0.200 \mathrm{ml} / \mathrm{l}$ to $0.600 \mathrm{~m} \ell / \ell$. Recently, Velíšec, Wlasow, Gomulka, Svobodova \& Novotny (2007) indicated that 2-Phenoxyethanol also has a relatively low therapeutic index, reported as 1:2.6.

The majority of fishes anaesthetised throughout their translocation of fishes from Sea World to uShaka Marine World showed optimal anaesthesia at the concentration of $0.150 \mathrm{~m} \ell / \ell$, with some species effectively anaesthetised at lower dosages, and one species ( $R$. canadum) requiring additional anaesthetic to facilitate successful removal.

Yanar \& Kumlu (2001) and Velíšec et al. (2007) indicated that the effective concentration of an anaesthetic leading to induction in fishes varied according to their sex, age, water quality parameters, overall biomass and physiological state, and the duration of the exposure. All T. botla from the shark tank were juveniles of less than $20 \mathrm{~cm}$ in length. Those from the open ocean exhibit were adults of approximately $50 \mathrm{~cm}$ in length. Velíšec \& Svobodova (2004a) indicated that juvenile rainbow trout, Oncorhynchus mykiss Walbaum, 1792, are more sensitive to 2Phenoxyethanol than adults. This could explain the difference in effective induction of $T$. botla from the shark tank and open ocean exhibit, where more than double the dosage of 2-Phenoxyethanol for the adult fish from the open ocean exhibit was required for the same anaesthetic effect. Once the desired level of anaesthesia had been reached in both exhibits, several hours passed before all fishes were eventually removed. Their anaesthetic state remained stable and did not progress with time.

Velíšec \& Svobodova (2004a); Velíšec et al. (2007) also consider that sensitivity to anaesthetics is influenced by the enhancement of decreasing or low dissolved oxygen concentration, but the most important factor affecting the anaesthetic efficiency of 2-Phenoxyethnol is temperature, where higher temperatures produce better anaesthetic efficiency (Velíšec \& Svobodova 2004b). Dissolved oxygen levels dropped slightly in each exhibit from the beginning of the exercise to first induction, but remained stable at $71.9 \%$ and $72.9 \%$ for the open ocean exhibit and shark tank, respectively. This initial drop is thought to be the result of shutting down the filtration processes and incoming make-up water just prior to the introduction of the first anaesthetic increment. The last dissolved oxygen reading for the open ocean exhibit was taken at induction of the last remaining individual fish, $R$. canadum, and was notably higher at $89.6 \%$ after the removal of all other fishes, which indicates that the stable dissolved oxygen levels observed reflect the equilibrium between biomass and maintained artificial aeration. Aeration is therefore recommended for similar future exercises.

Yanar \& Kumlu (2001) stated, following an experiment with European seabass, Dicentrarchus labrax Linnaeus, 1758, that an increase in anaesthetic concentration decreased the induction time. This is evident in comparing the time to induction at $0.150 \mathrm{ml} / \mathrm{l}$, 
obtained at $330 \mathrm{~min}$ and $70 \mathrm{~min}$ for the open ocean exhibit and shark tank respectively, but excitation was displayed in all carangids in the shark tank but not in those from the open ocean exhibit. It is therefore possible that time to anaesthetic concentration, and not necessarily the concentration alone could have played an important role in controlling the onset of excitation in this family of fishes.

Molinero \& Gonzalez (1995) consider that reactions of fishes to 2-Phenoxyethanol and MS-222 include a change in respiratory rate and pigmentation. Tytler \& Hawkins (1981) suggested that retaining fishes in an anaesthetic bath for too long leads to the fading of respiration and finally complete respiratory and cardiac failure, but Hajec, Kłyszejko \& Dziaman (2006) confirmed that lower effective concentrations of the anaesthetic clove oil provided longer periods of general anaesthesia with respiration being maintained. Although fishes in both exhibits became increasingly less responsive to external stimuli, such as sudden movements and the presence of divers in the water through the progression of concentration increments and time, no obvious pigmentation changes or notable changes in respiration rates for the entire duration of the exercise were observed. Shoaling species such as Southern pompano, Trachinotus africanus Smith, 1967, Shrimp scad, Alepes djedaba Forsskal, 1775, and Coastal kingfish, Carangoides caeruleopinnatus Ruppell, 1830, assumed tight shoals until just prior to anaesthesia when they became disorientated, and dispersed throughout the water column before losing equilibrium.

No information is available in which the successful use of 2-Phenoxyethanol to anaesthetise adult $C$. leucas, and $C$. taurus, is outlined. Both these species reacted favourably to this anaesthetic, allowing safe anaesthesia without risk of injury to the sharks or handlers, at the concentration of $0.150 \mathrm{ml} / \mathrm{l}$ and $72.9 \%$ dissolved oxygen, and $70 \mathrm{~min}$.

The translocation of all fishes from one public aquarium to another is a rare occurrence, and one which requires careful planning. The use of 2-Phenoxyethanol as a reliable and stable anaesthetic was paramount to the successful and relatively stressfree procedure which included transportation by road.

\section{REFERENCES}

DEACON, N., WHITE, H., \& HECHT, T. 1997. Isolation of the effective concentration of 2-Phenoxyethanol for anaesthesia in the spotted grunter (Pomadays commersonnii), and its effect on growth. Aquarium Sciences and Conservation, 1: 19-27.

DUNN, R.F. \& KOESTER, D.M. 1985. Anesthetics in elasmobranchs: A review with emphasis on halothane-oxygen-nitrous oxide. Journal of Aquariculture and Aquatic Sciences, 5:44-52.

HAJEK, G.J., KLYSZEJKO, B. \& DZIAMAN, B. 2006. The anaesthetic effect of clove oil on common carp (Cyprinus carpio L.). Acta Ichthyologica et Piscatoria, 36:93-97.

HSEU, J., YEH, S., CHU, Y. \& TING, Y. 1998. Comparison of efficacy of five anesthetics in Goldlined Sea Bream (Sparus sarba). Acta Zoologica Taiwanica, 9:35-41.

INOUE, L.A.K.A., DOS SANTOS NETO, C. \& MORALES, G. 2004. Standardization of 2-phenoxyethanol as anaesthetic for juvenile Brycon cephalus (Gunther, 1867): the use in field procedures. Ciência Rural (Santa Maria), 34:563-565.

KAISER, H. \& VINE, N. 1998. The effect of 2-Phenoxyethanol and transport packing density on the post-transport survival rate and metabolic activity in the goldfish (Carassius auratus). Aquarium Sciences and Conservation, 2:1-7.

MOLINERO, A. \& GONZALEZ, J. 1995. Comparative effects of MS 222 and 2-Phenoxyethanol on gilthead sea bream (Sparus aurata L.) during confinement. Comparative Biochemistry and Physiology, 111:405-414.

TYTLER, P. \& HAWKINS, A.D. 1981. Vivisection, anesthetics and minor surgery, in Aquarium systems, edited by A.D. Hawkins. New York: Academic Press.

VELÍŠEK, J. \& SVOBODOVA, Z. 2004a. Anaesthesia of Rainbow Trout (Oncorhynchus mykiss) with 2-phenoxyethanol: Acute toxicity and biochemical blood profile. Acta Veterinaria Brno, 73:379-384.

VELÍŠEK, J. \& SVOBODOVA, Z. 2004b. Anaesthesia of Common Carp (Cyprinus carpio L.) with 2-phenoxyethanol: Acute toxicity and effects on biochemical blood profile. Acta Veterinaria Brno, 73:247-252.

VELÍŠEK, J., WLASOW, T., GOMULKA, P., SVOBODOVA, Z. \& NOVONTY, L. 2007. Effects of 2-Phenoxyethanol anaesthesia on sheatfish (Silurus glanis L.). Veterinarni Medicina, 52: 103-110.

YANAR, M. \& KUMLU, M. 2001. The anaesthetic effects of quinaldine Sulphate and/or Diazepam on Sea Bass (Dicentrarchus labrax) juveniles. Turk Veterinerlik ve Hayvancilik Dergisi, 25:185-189. 